\title{
Investigation of creativity perceptions of pre-service teachers and child development specialists based on different variables
}

\section{Çocuk gelişimci ve farklı branşlardaki öğretmen adaylarının yaratıcılık algilarının farklı değişkenlere göre incelenmesi}

\begin{abstract}
Article History
Received : 10 September 2020 Revised : 22 September 2020

Accepted : 24 September 2020
\end{abstract}

Article Type

Research Article

\section{Makale Geçmişi \\ Geliş : 10 Eylül 2020 \\ Düzeltme : 22 Eylül 2020 \\ Kabul : 24 Eylül 2020}

\section{Makale Türü}

Araștırma Makalesi

\author{
Serap Gürak-Özdemir ${ }^{1}$, Rıza Özdemir ${ }^{2}$
}

\begin{abstract}
This study aimed to investigate how pre-service child development specialists and pre-service teachers from different majors understand their creativity perceptions and how these perceptions could differ based on a range of variables. There were 316 participants selected with the convenience sampling method. Data were collected by using a demographic questionnaire and the Kaufman Domains of Creativity Scale (K-DOCS). Mann-Whitney U and Kruskal Wallis, and Spearman correlation were used to analyze the data. The findings revealed significant relationships between creativity domains and gender, previously taken creativity course, major, teachers' attitudes towards creativity, and strategy knowledge. However, there was no significant difference between creative domains and the most creative age teachers think, class standings, and teachers' attitudes toward negative behaviors. This study indicated the importance of the majors and their curriculum. Including creativity content in teacher training curricula is crucial to developing skills needed in the 21 st Century.
\end{abstract}

Keywords: Creativity, Child development, Pre-service teachers, Kaufman domains of creativity scale

Öz: Bu çalışmanın amacı farklı branşlardan öğretmen ve çocuk gelişimci adaylarının yaratıclık algılarını ve bu algıların çeşitli değişkenlere göre nasıl farklılaştığını araştırmaktır. Bu çalışmada, elverişli örnekleme yöntemi kullanılarak seçilen 316 katılımcı bulunmaktadır. Veriler bir demografik bilgi formu ve Kaufman Yaratıcılık Alanları Ölçeği (K-DOCS) kullanılarak toplanmıştır. Verilerin analizinde Mann-Whitney U ve Kruskal Wallis ve Spearman korelasyonu kullanılmıştır. Bulgular, yaratıcılık alanları ile cinsiyet, daha önce yaratıcılık kursu alma, bölüm, öğretmenlerin yaratıcılığa karşı tutumları ve strateji bilgisi arasında önemli ilişkiler olduğunu ortaya koymuştur. Öte yandan, yaratıcılık alanları ile öğretmenlerinin düşündüğ̈̈ en yaratıcı yaş, sınıf düzeyi ve öğretmenlerin olumsuz davranışlara karşı tutumları arasında anlamlı bir fark bulunamamıştır. Bu bulgular literatürle bağlantılı olarak tartışılmıştır. Bu çalışma, bölümlerin ve müfredatlarının önemini açıç̧a göstermiştir. Bunun nedeni, müfredatın öğretmen adaylarının düşüncelerini şekillendirmesidir. 21. Yüzyılda ihtiyaç duyulan becerileri elde etmek için müfredata yaratıcılık kurslarının dahil edilmesi konusunda öncü adımlar atmak çok önemlidir. Çalışmanın sınırlılıkları ve eğitimde gelecekteki etkileri de tartışılmıştır.

Anahtar Kelimeler: Yaratıcılık, Çocuk gelişimi, Öğretmen adayları, Kaufman yaratıcılık alanları ölçeği

\footnotetext{
*Some data in this study used for a presentation at EJER 2019 conference.

Corresponding Author: Riza Özdemir

1 Ankara University, Graduate School of Health Science, Child Development Department, serapgurakozdemir@gmail.com, ORCID: https://orcid.org/0000-0003-0996-4458

2 Zonguldak Bülent Ecevit University, Ereğli Faculty of Education, Special Education Department, voss8@hotmail.com, ORCID https://orcid.org/0000-0001-9794-9762
} 


\section{INTRODUCTION}

In the changing and developing world, students who have only knowledge have difficulty adapting themselves to life and are more likely to get behind. At this point, successful adaptation depends upon student's ability to think through how and where to use the information they possess. Thus, one of the important skills that students need to have is creative thinking (Gök \& Erdoğan, 2011; Puccio, Mance, Switalski, \& Reali, 2012).

Creativity provides opportunities to look at issues from different angles and to solve them by generating innovative and useful ideas (Sternberg \& Lubart, 1999). Creativity is free of judgment, on-going, and a productive process (Yaşar \& Aral, 2010). In this process, students critique current knowledge, realize deficiencies, and find solutions or products by using their imaginations (Emir et al., 2004; Puccio et al. 2012). Everyone is born with the potential for creativity (Miller, Vehar, Firestein, Thurber, \& Nielsen, 2011), and this potential could be improved by educating students about creativity. However, we usually undermine this potential in the education system instead of supporting it. As a result, creativity skills, which are very high in early childhood, could gradually decrease over time.

Since today's education system is information-oriented, students have a hard time realizing and improving their creativity skills (Puccio et al., 2012). This education system negatively affects students' creative potential. If we expand this issue, this system mostly focuses on convergent teaching which is how to use existing information instead of critiquing old ideas and generating new ones (Beghetto, 2007). However, in this rapidly developing world, it is very difficult to predict what information will be valid in the future and will work for us (Parnes, 1992; Puccio et al.). Additionally, because teachers could view creative ideas as disruptive, they might suppress creative thinking and expression in their classrooms (Kennedy, 2005). Therefore, the beliefs and attitudes of teachers toward creativity are important issues in the classroom. Torrence (1963) emphasized that teachers viewed the ideal students as compliant and conforming and linked creativity skills to non-conformity, impulsivity, and disruptive behavior. This perspective characterizes creative students unfavorably and undermines their creative potential. However, Gurak-Ozdemir, Acar, Puccio, and Wright (2019) investigated relationships between the ideal students and teachers' creative perceptions and found that teachers favor students based on their creativity personalities. This directs us that creativity in the classroom could be enhanced if teachers understand their creativity perceptions and know how to use their skills in the classroom. 
In the literature, many researchers looked into the relationships between pre-service teachers and creativity from different angles. Some studies were related to teacher education and examined the creativity of preservice teachers in different majors. Özben and Argun (2005) compared the creativity skills of pre-service teachers in art, social studies, and science majors, using verbal Form A of the Torrance Test of Creative Thinking. Özben and Argun reported pre-service social studies teachers scored significantly higher than art and science majors. They also found that pre-service teachers who graduated from vocational high schools had higher creativity scores than those from academic high schools. Researchers noted that higher creatvitiy scores could be related to differences in childhood education and creative drama lessons. Additionally, female pre-service teachers perform better on fluency and flexibility. There were no significant differences among majors based on age and parents' education. Görgen and Karaçelik (2009) compared first-year and fourth-year pre-service teachers in early childhood and science programs using verbal Form-A of the Torrance Test of Creative Thinking. They found the fourth-year preservice teachers had higher scores in fluency, flexibility, and originality than the first-year pre-service teachers in early childhood programs. But there was not any difference among majors. İşleyen and Küçük (2013) compared the creativity skills of pre-service teachers in early childhood education and science education. They used verbal form-A and figural form-A of the Torrance Test of Creative Thinking. They found there was no significant difference betweem majors in terms of verbal fluency, flexibility, and originality. However, in terms of gender, there was a difference in these verbal items. Conversely, majors and gender did not differ on originality, abstractness, and resistance. But, major had a significant difference in terms of elaboration, and elementary teachers performed better than others.

Ulusoy-Y1lmaz and Yildız (2019) investigated the creative thinking skills of pre-service music teachers by using the creativity scale developed by Whetton and Cameron. These researchers found the creative thinking skills of pre-service music teachers were above average. They found that these participants' creativity skills did not differ based on gender, the type of secondary school which they graduated, the number of musical instruments they play, and the presence of family members who have a music background. Topoğlu (2015) worked with 1028 pre-service teachers in art, music, elementary education, science, and social studies programs and investigated their creativity skills by using a "how creative you are" scale. Topoğlu (2015) found pre-service teachers' creativity levels were below average and their levels did not differ based on gender, age, high school types, or frequency of participating in artistic activities. However, pre-service science teachers had higher creative scores than pre-service elementary teachers. Korur and Yllmaz (2020) examined the creativity of pre-service teachers in mathematics, science, and primary and early childhood 
education programs by using the Kaufman Domains of Creativity Scale (K-DOCS). They found pre-service science teachers significantly perform better in the science/mechanical domain than those in other education programs. Additionally, pre-service teachers in primary education had higher in the everyday domain than pre-service teachers in mathematics education. In terms of the scholarly domain, pre-service teachers in elementary education scored higher than early childhood education, and science pre-service teachers performed higher than students in early childhood and mathematics education. To sum up, researchers studying the creative thinking of pre-service teachers often compared students pursuing different majors. They usually compared science and art teachers with other majors because the literature showed these two majors could be more creative than other majors. Additionally, researchers in this area often used the Torrance Test of Creative Thinking. In light of these practices, we focused our research on pre-service teachers that are in child development, elementary education, special education, and early childhood education majors.

Runco (1996) observes that children are highly creative in early lives, but they might not show creativity when they grow up. One of the reasons for this change is the environment children encounter. In this environment, teachers play a critical role fostering children's creativity (Sharp, 2004). Runco (2003) emphasizes the importance of teachers understanding and showing an interest in children's creative potential, behaviors and ideas. How a teacher or child development specialist perceives creativity will effect their interactions with children. In this study, we aim to investigate how pre-service teachers and pre-service child development specialists understand their creativity perceptions and how these perceptions could differ based on a variety of variables. The following research questions are investigated:

1. To what extent the perceptions of pre-service teachers and child development specialists could differ based on gender, major, class standing, creativity course is taken, teachers' attitudes?

2. How are the relationships between creativity perceptions and age, the number of strategies, gender, major, class standing, creativity course is taken, and teachers' attitudes?

\section{METHOD}

This study uses a descriptive design to investigate the creativity perceptions of pre-service teachers from different majors and pre-service child development specialists according to a variety of variables. Descriptive design is one of the quantitative research designs and aims to understand the 
relationships between dependent and independent variables without manipulating them (Sloman, 2010).

\section{Participants}

In this study, pre-service teachers and pre-service child development specialists were participants. These participants were selected by using the convenience sampling method. Of these participants, pre-service teachers were from different majors: (a) early childhood education, (b) elementary education, (c) special education, and (d) child development specialist. Data collected from freshman students to senior students at the university level. In this study, there were 316 participants, and the mean of participants' age was 22 years old (Range= 18-38). Demographic information about participants is presented in Table 1.

Table 1. Demographic information about participants

\begin{tabular}{llll}
\hline Variables & Categories & $\mathbf{n}$ & $\%$ \\
\hline Gender & Male & 88 & 27.8 \\
& Female & 228 & 72.2 \\
\hline Major & Child Development & 100 & 31.6 \\
& Elementary Education & 51 & 16.1 \\
& Early Childhood & 68 & 21.5 \\
& Education & 97 & 30.7 \\
& Special Education & 70 & 22.2 \\
\hline Class standings & Freshman (1. Year) & 101 & 32 \\
& Sophomore (2. Year) & 73 & 23.1 \\
& Junior (3. Year) & 72 & 22.8 \\
\hline Creativity Course Taken & Yenior (4. Year) & 91 & 28.8 \\
& No & 225 & 71.2 \\
\hline
\end{tabular}

\section{Instruments}

In this study, a demographic questionnaire and the Kaufman Domains of Creativity Scale (KDOCS) were used. Şahin (2016) adapted this scale to Turkish and conducted its reliability and validity research. The Cronbach alpha for the instrument was .90. This instrument was a 5 Likert scale and had 41 items and 5 domains: (a) every day, (b) scholarly, (c) performance, (d) scientific/mechanical, and (e) artistic. 


\section{Data Collection Procedure}

Researchers first obtained the ethics committee approval from the University Ethical Committee to conduct this study. Then, they informed participants about the study and clearly emphasized the data would be only used for this study under ethical and scientific principles such as giving participants the right to withdraw from the research, emphasizing the voluntary basis of the research, and avoding any harmful acts. Then, researchers asked participants to join this study voluntarily. If participants accepted this invitation, the researchers provided a bundle of the consent form, a demographic questionnaire, and the Turkish version of the K-DOCS. When participants completed all forms, they were collected and prepared for data analysis.

\section{Data Analysis}

Participants' responses were coded anonymously. Then, their data were entered into the SPSS 20 version. At the beginning of the analysis, researchers investigated the characteristics of the sample. A Shapiro-Wilk's test (p.> .05) (Shapiro \& Wilk, 1965) and the investigation of skewness and kurtosis measures, and data histograms demonstrated the sample data were not normally distributed. Additionally, a non-parametric Levene's test was run to verify the equality of variances in the samples (p.> .05) (Nordstokke, Zumbo, Cairns, \& Saklofske, 2011). In the light of these results, the researchers decided to conduct both a Mann-Whitney $U$ and Kruskal Wallis procedure to analyze the differences between variables, and a Spearman correlation to analyze the relationships between independent and dependent variables.

\section{RESULTS}

In this research, the Mann-Whitney $U$ analysis was conducted to investigate the differences between creativity domains and gender and previously taken creativity courses in the university. One finding indicated there was a significant difference between science/mechanical creativity and gender. Male students $(\mathrm{Mdn}=186.9)$ showed higher science/mechanical creativity scores than female students $(\mathrm{Mdn}=147.5), \mathrm{U}=7533.5, \mathrm{p}=.001$. On the other hand, female students $(\mathrm{Mdn}=164.7)$ demonstrated better scores on everyday creativity than male students $(\mathrm{Mdn}=142.3)$, $\mathrm{U}=8610.5, \mathrm{p}=.05$. Another finding revealed that there was a significant difference between everyday creativity and previously taken creativity courses. Students who took a creativity course $(\mathrm{Mdn}=175.78)$ showed higher everyday creativity scores than students who didn't take a creativity course (151.51), $\mathrm{U}=8665, \mathrm{p}=.032$ (See Table 2). 
Table 2. Mann-Whitney $U$ results for gender and creativity course

\begin{tabular}{|c|c|c|c|c|c|c|}
\hline Domains & & & $\bar{x}$ & ss & $U$ & $p$ \\
\hline \multirow[t]{4}{*}{ SD } & Gender & Male & 163.4 & 14379 & 9601 & .55 \\
\hline & & Female & 156.6 & 35707 & & \\
\hline & Creativity & Yes & 159.4 & 14507 & 10154 & .910 \\
\hline & Course & $\mathrm{No}$ & 158.13 & 35579 & & \\
\hline \multirow[t]{4}{*}{ SMD } & Gender & Male & 186.9 & 16446.5 & 7533.5 & $.001 *$ \\
\hline & & Female & 147.5 & 33639.5 & & \\
\hline & Creativity & Yes & 165.86 & 15093.5 & 9567.5 & .362 \\
\hline & Course & No & 155.52 & 34992.5 & & \\
\hline \multirow[t]{4}{*}{ PD } & Gender & Male & 158.3 & 13931.5 & 10015.5 & .98 \\
\hline & & Female & 158.5 & 36154.5 & & \\
\hline & Creativity & Yes & 165.69 & 15078 & 9583 & .373 \\
\hline & Course & $\mathrm{No}$ & 155.59 & 35008 & & \\
\hline \multirow[t]{4}{*}{ ED } & Gender & Male & 142.3 & 12526.5 & 8610.5 & $.05^{*}$ \\
\hline & & Female & 164.7 & 37559.5 & & \\
\hline & Creativity & Yes & 175.78 & 15996 & 8665 & $.032 *$ \\
\hline & Conise & No & 151.51 & 34090 & & \\
\hline \multirow[t]{4}{*}{$\mathrm{AD}$} & Gender & Male & 151.5 & 13332 & 9416 & .39 \\
\hline & & Female & 161.2 & 36754 & & \\
\hline & Creativity & Yes & 171.59 & 15615 & 9046 & .105 \\
\hline & & $\mathrm{No}$ & 153.20 & 34471 & & \\
\hline
\end{tabular}

$* \mathrm{p}<.05 ; \mathrm{SD}=$ Scholarly Domain; SMD = Science $/$ Mechanical Domain; $\mathrm{PD}=$ Performance Domain; ED $=$ Everyday Domain; AD= Artistic Domain

Kruskal Wallis $\mathrm{H}$ and pairwise comparison as a post-hoc were conducted to investigate the differences between creativity domains and major, class standings, the most creative age teachers think, teachers' attitudes towards creativity, and teachers' attitudes toward negative behaviors. The findings demonstrated there was no significant difference between creative domains and the most creative age teachers think, class standings, and teachers' attitudes toward negative behaviors $(\mathrm{p}>.05)$.

There was a significant difference between the major of students and scholarly creativity $\mathrm{H}(3)=18.84, \mathrm{p}=.000$. The pairwise comparison revealed students in the special education program 
$(\mathrm{Mdn}=168.8)$ had higher scholarly creativity scores than students in the early childhood education program (Mdn=119.2), $\mathrm{U}=-49.5, \mathrm{p}=.004$. On the other hand, a significant difference was found between the major of students and everyday creativity $\mathrm{H}(3)=19.84, \mathrm{p}=.000$. Pairwise comparison showed students in the child specialist program ( $M d n=191.1)$ respectively had higher everyday creativity scores than students in the early childhood education program ( $M d n=135.9), U=55.1$, $\mathrm{p}=.001$, students in the elementary education program $(\mathrm{Mdn}=139.3), \mathrm{U}=51.8, \mathrm{p}=.006$, and students in the special education program ( $M d n=150.8), U=40.2, p=.012$.

There was a significant difference between teachers' attitudes toward creativity and everyday creativity $\mathrm{H}(2)=11.32, \mathrm{p}=.003$, and artistic creativity $\mathrm{H}(2)=6.78, \mathrm{p}=.034$. Students who claimed supportive attitudes towards creativity when they teach in their future classrooms $(\mathrm{Mdn}=164.4)$ showed higher everyday creativity scores than students who were uncertain about their attitudes towards creativity $(\mathrm{Mdn}=111.2), \mathrm{U}=-53.2, \mathrm{p}=.001$. Additionally, students who have supportive attitudes towards creativity $(\mathrm{Mdn}=161.9)$ showed higher artistic creativity scores than students who are uncertain about their attitudes towards creativity $(\mathrm{Mdn}=117.4), \mathrm{U}=-44.6, \mathrm{p}=.041$.

Spearman's correlation demonstrated important relationships between variables (See Table 3). First, older students had better strategy knowledge than younger students ( $\mathrm{r}=.37)$. Moreover, older students performed better in most of the creative domains. In addition to the age, there are small relationships between the strategy knowledge and the domains except the performance domain. This indicated students who have better strategy knowledge related to creativity could perfom better in these domains than students who have limited strategy knowledge.

Table 3. The correlation results of all variables

\begin{tabular}{llllllll}
\hline & 1. & 2. & 3. & 4. & 5. & 6. & 7. \\
\hline 1. Age & 1 & & & & & & \\
2. The number of strategy & $.37 *$ & 1 & & & & & \\
3. SD & $.15^{*}$ & $.16^{*}$ & 1 & & & & \\
4. SMD & $.11^{*}$ & $.14^{*}$ & $.34^{*}$ & 1 & & & \\
5. PD & .04 & .08 & $.55^{*}$ & $.32^{*}$ & 1 & & \\
6. $\mathrm{ED}$ & $.12^{*}$ & $.16^{*}$ & $.59^{*}$ & $.14^{*}$ & $.40^{*}$ & 1 & \\
$7 . \mathrm{AD}$ & .09 & $.17^{*}$ & $.42^{*}$ & $.45^{*}$ & $.42^{*}$ & $.40^{*}$ & 1 \\
\hline
\end{tabular}

${ }^{*} \mathrm{p}<.05 ; \mathrm{SD}=$ Scholarly Domain; $\mathrm{SMD}=$ Science/Mechanical Domain; $\mathrm{PD}=$ Performance Domain; $\mathrm{ED}=$ Everyday Domain; $\mathrm{AD}=$ Artistic Domain 


\section{CONCLUSION and DISCUSSION}

This study investigated how pre-service teachers and pre-service child development specialists understand their creativity perceptions and how these perceptions could differ based on a variety of variables. Analyzing the data revealed valuable findings of creativity and the perceptions of preservice professionals in accordance with domain-specific creativity.

The difference between creativity and gender has been investigated in the literature. Abraham (2016) summarized empirical studies and noted that there has not been any dominant gender effect on creativity. Ulusoy-Yilmaz and Yildız (2019) did not find a significant difference between the gender of pre-service teachers and creativity. In addition to this study, Topoğlu (2015) also did not find a significant difference about them. Additionally, Yenilmez ve Yolcu (2007) focused on teachers and found no difference between gender and teacher. On the other hand, Altın (2010) found a significant difference between creativity and gender in favor of female teachers. İşleyen and Küçük (2013) also found a significant difference between these variables. In light of previous mixed results about gender and creativity, our study demonstrated significant findings about these variables. First of all, male pre-service teachers were favored in the science/mechanic domain where female pre-service teachers scored better in everyday creativity. These findings revealed females and males showed different results on different creativity domains. Thus, our findings contribute to the literature that there is no clear distinction of how gender affects the creativity of pre-service teachers.

Major is a critical component in the education system because pre-service teachers gather background knowledge based on their fields and shape their teaching philosophy to provide an effective education. In this respect, investigating how different majors approach creativity enlightens the way teachers encourage creativity behaviors and awareness in the classroom. In this study, one of the significant findings was that pre-service teachers in special education performed better in the scholarly domain than pre-service teachers in early childhood. Considering the scholarly domain focuses on higher-order thinking in word attack skills (Şahin, 2016), special education pre-service teachers could contribute to students' education and encourage students to demonstrate their creativity by using their writing and reading skills. Additionally, pre-service child specialists showed significantly higher performance in the everyday domain than pre-service teachers in early childhood, special education, and elementary education. Teachers work with students in structured and unstructured settings. When teachers work with young students, settings could usually be unstructured. Thus, the finding showed child development specialists could 
support young students more in the everyday domain than all other pre-service teachers. In the literature, there are some studies that have compared different majors on creativity. One study conducted by İşleyen and Küçük (2013) didn’t find any major differences. On the other hand, Topoğlu found significant differences among different majors. Pre-service teachers in art, social studies, and science majors had higher scores than pre-service music teachers. And also, pre-service teachers in art, social studies, science majors had higher scores than pre-service elementary teachers. Moreover, Özben and Argun (2005) compared pre-service teachers in science, social studies, and art education and found that pre-service teachers in social studies had higher scores than others. Korur and Yilmaz (2020) compared pre-service teachers in elementary, early childhood, science, and mathematics departments by using K-DOCS. In terms of everyday domain, students in the elementary department had higher scores than students in mathematics. And, students in the science department performed better in the science/mechanics domain than other students. In light of these findings, even though the literature had mixed results, our study showed similar results with previous studies with regards to demonstrating significant differences between major and creativity. In brief, the curriculum in different majors should cover creativity and see how creativity affects the education system.

In the classroom, teachers' beliefs could affect how they approach their students. In the literature, many researchers emphasized that teachers have seen creative skills as intolerable behaviors such as non-conformity, impulsivity, and disruptive (Beghetto, 2007; Torrence, 1963). However, this study revealed any pre-service teachers did not have negative opinions towards creative skills in the classroom. Important to say that having positive attitudes is a starting point to encourage creativity and to handle creativity related problems. Additionally, another finding was that pre-service teachers who support creativity in the classroom had higher scores in everyday creativity and artistic domains than hesitant pre-service teachers.

The beliefs and attitudes of teachers towards creativity are important issues in the classroom. Torrence (1963) emphasized teachers viewed the ideal students as compliant and conforming and linked creativity skills to non-conformity, impulsivity, and disruptive. This perspective makes creative students unfavorably and undermine their creative potentials. However, Gurak-Ozdemir, Acar, Puccio, and Wright (2019) investigated the ideal students and teachers' creative perceptions and found that teachers favor students based on their creativity personalities. And, this directs us that creativity in the classroom could be enhanced if teachers understand their creativity perceptions and know how to use their skills in the classroom. Senemoğlu (1996) noted if teachers are aware of their creativity skills, then they could organize the environment to lead students' 
creativity skills. Akcanca ve Özsevgeç (2016) also explained that this awareness could help teachers to realize the factors that negatively affect the development of creativity in classroom activities. Our study supports previous discussions because pre-service teachers had positive attitudes towards creativity and that would enhance opportunities to set a creative friendly environment.

Education in the classroom is generally based on knowledge. Teachers provide information to students and become the center of instruction. Beghetto (2010) emphasized teachers are eager to use this convergent teaching because they were educated in this way. As a result, creativity is given initiative to teachers in the classroom. However, this situation could be reversed by a dint of instructing pre-service teachers about creativity (Puccio et al., 2012). One of the findings demonstrated pre-service teachers who took creativity related courses obtained higher scores in the everyday domain than pre-service teachers who didn't take the course. This finding highlighted the similar previous results that creativity should be a part of the education system. On the other hand, Görgen and Karaçelik (2009) compared the class standings of pre-service teachers and found the fourth-year preservice teachers had higher scores in fluency, flexibility, and originality than the first-year pre-service teachers in the early childhood department. Our finding was the opposite of this study, and we found no difference between creativity and class standings. However, it is important to mention that strategy knowledge was correlated with creativity domains. That led us to creativity perceptions and knowledge of pre-service teachers determine whether they take any course at the university level instead of class standings. In this respect, universities must add creativity courses for pre-service teachers who would work with students at any age level.

In conclusion, we conducted this study to understand pre-service teachers' creativity perceptions and how these perceptions could differ based on a variety of variables. This study clearly indicated the importance of the majors and their curriculum. The reason is that curriculum shapes pre-service teachers' mindsets. And, the pre-service teachers will pass on their perceptions to future students. It is clear that when these teachers start teaching, they will provide what they learned at the university level. Thus, it is crucial to take steps beforehand about including creativity courses to the curriculum to achieve skills needed in $21^{\text {st }}$ Century.

There are some limitations in this study, so future researchers should approach the results cautiously. We will also provide some suggestions for future studies. First, our focus was on preservice teachers who would work with young students. In the future, it would be better to expand this population to generalize the findings for all majors. In addition to this, comparing teachers and pre-service teachers based on their majors could bring new perspectives about what happens after 
starting to teach. Second, this study is a capture of the current situation of pre-service teachers. In the future, this study could be replicated to demonstrate how perceptions of these teachers might change. Additionally, it would be better to conduct experimental studies that show the effectiveness of creativity courses on teachers' perceptions. Finally, data weren't normally distributed and we had to use non-parametric analysis methods. If future researchers use parametric analysis methods, the results could be more powerful.

\section{REFERENCES}

Abraham, A. (2016). Gender and creativity: An overview of psychological and neuroscientific literature. Brain Imaging and Behavior, 10(2), 609-618. DOI 10.1007/s11682-015-9410-8

Altın, B. (2010). İlköğretimde görevli ögretmenlerin örgütsel băglllkklaryla yaratıcllklar ilișkisi. (Unpublished Master Thesis). Maltepe University, İstanbul.

Beghetto, R. A. (2007). Ideational code switching: Walking the talk about supporting student creativity in the classroom. Roeper Review, 29, 265-270.

Beghetto, R. A. (2010). Creativity in the classroom in J.C. Kaufman, R.J. Sternberg (Eds.), Cambridge bandbook of creativity, Cambridge University Press, New York, USA (2010), pp. 447-465

Doane, D. P., \& Seward, L.E. (2011). Measuring skewness. Journal of Statistics Education, 19(2), 1-18.

Emir, S., Ateş, S., Aydın, F., Bahar, M., Durmuş, S., Polat, M., \& Yaman, H. (2004). Öğretmen adaylarının yaratıcılık düzeyleri, Abant İzæet Baysal Üniversitesi Sosyal Bilimler Enstitüsü Dergisi, 2(9), 105-116.

Gök, B., \& Erdoğan, T. (2011). The investigation of the creative thinking levels and the critical thinking disposition of pre-service elementary teachers. Ankara University Journal of Faculty of Educational Sciences, 44(2), 29-51.

Görgen İ., \& Karaçelik S. (2009). Okul öncesi öğretmenliği ve fen bilgisi öğretmenliği öğrencilerinin yaratıcı düşünme beceri düzeylerinin karşılaştırmalı incelenmesi. Muğla Üniversitesi Sosyal Bilimler Enstitüsü Dergisi, 23, 129-146.

Gurak-Ozdemir, S., Acar, S., Puccio, G., \& Wright, C. (2019). Why do teachers connect better with some students than others? Exploring the influence of teachers' creative-thinking preferences. Gifted and Talented International, 34(1-2)102-115.

İşleyen, T., \& Küçük, B. (2013). Öğretmen adaylarının yaratıcı düşünme düzeylerini farklı değișkenler açısından incelemesi. Mustafa Kemal Üniversitesi Sosyal Bilimler Enstitüsü Dergisi, 10(21), 199-208.

Kennedy, M. (2005). Inside teaching: How classroom life undermines reform. Cambridge, MA: Harvard University Press.

Korur, F. \& Yilmaz, T. (2020). Analysis of kaufman domains of creativity of students in in mathematics and science and primary education departments. SDU International Journal of Educational Studies, 7(1), 167-187. DOI: 10.33710/sduijes.678399 
Miller, B., Vehar, J., Firestein, R., Thurber, S., Nielsen, D. (2011). Creativity unbound: An introduction to creative process (5th ed). Evanston, IL: FourSight, LLC.

Nordstokke, D. W., Zumbo, B. D., Cairns, S. L., Saklofske, D. H. (2011). The operating characteristics of the nonparametric Levene test for equal variances with assessment and evaluation data. Practical Assessment, Research \& Evaluation, 16(5). Available online: http://pareonline.net/getvn.asp?v $=16 \& n=5$

Özben, Ş., \& Argun, Y. (2005). Buca eğitim fakültesi öğrencilerinin yaratıcllık boyutları puanlarının karşılaştırılması. Dokuz Eylül Üniversitesi Buca Eğitim Fakültesi Dergisi,18, 16-23.

Parnes, S. J. (1992). Sourcebook for creative problem solving. Buffalo: Creative Education Foundation Press.

Puccio, G., Mance, M., Barbero Switalski, L., \& Reali, P. D. (2012). Creativity rising: Creative thinking and creative problem solving in the 21st century. Buffalo, NY: ICSC.

Runco, M. A. (1996). Creativity from childhood through adulthood: The developmental issues (New Directions for Child Development No. 72). San Francisco, CA: Jossey-Bass.

Runco, M.A. (2003). Education for creative potential, Scandinavian Journal of Educational Research, 47(3), 317-324.

Senemoğlu, N. (1996). Yaratıcllk ve ögrretmen nitelikleri. Yaratıcllk ve eğitim paneli. Ankara: Kara Harp Okulu. Retrieved from: http://yunus.hacettepe.edu.tr/ n.senem/makaleler/yaratici.htm

Shapiro, S. S., \& Wilk, M. B. (1965). An analysis of variance test for normality (complete samples). Biometrike, 52, (3/4), 591-611.

Sharp, C., 2004. Developing young children's creativity: What can we learn from research? Topic NFER, Issue 32. Available Online at https://nfer.ac.uk/publications/55502/55502.pdf

Sloman, K. N. (2010). Research trends in descriptive analysis. The Behavior Analyst Today, 11(1), $20-$ 35. http://dx.doi.org/10.1037/h0100686

Sternberg, R. J., \& Lubart, T. I. (1999). The concept of creativity: Prospects and paradigms. In R. J. Sternberg (Ed.), Handbook of creativity (pp. 3-15). New York: Cambridge University Press.

Şahin, F. (2016). Kaufman alanları yaratıcılık ölçeği'nin Türkçe'ye uyarlanması ve psikometrik Özelliklerinin incelenmesi. İlkögrretim Online, 15(3), 855-867. DOI: 10.17051/io.2016.70479

Topoğlu O. (2015). Eğitim fakültesinde öğrenim gören öğretmen adaylarının yaratıcıllk düzeylerinin çeşitli değisskenler açısından incelenmesi, ADÜ Örneği. International Journal of Social Science, 35, 371-383.DOI:http://dx.doi.org/10.9761/JASSS2861

Torrance, E. P. (1963). The creative personality and the ideal pupil. Teachers College Record, 65, 220 226.

Ulusoy Yılmaz, D., \& Yıldız, Y. (2019). Müzik öğretmen adaylarının yaratıcı düşünme becerilerinin çeşitli değişkenler açısından incelenmesi. Cumburiyet International Journal of Education, 8(2), 516-530. http://dx.doi.org/10.30703/cije.522714 
Yaşar, M. C., \& Aral, N. (2010). Yaratıcı düşünme becerilerinde okul öncesi eğitimin etkisi. Kuramsal Eğitim Bilim Dergisi, 3(2), 201-209. 